\title{
Platinum group elements and gold in ferromanganese crusts from Afanasiy-Nikitin seamount, equatorial Indian Ocean: Sources and fractionation
}

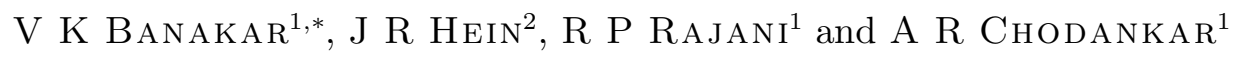 \\ ${ }^{1}$ National Institute of Oceanography, Dona Paula, Goa 403 004, India. \\ ${ }^{2}$ U.S. Geological Survey, MS999, Menlo Park, California, USA. \\ *e-mail:banakar@nio.org
}

\begin{abstract}
The major element relationships in ferromanganese (Fe-Mn) crusts from Afanasiy-Nikitin seamount (ANS), eastern equatorial Indian Ocean, appear to be atypical. High positive correlations $(r=0.99)$ between $\mathrm{Mn} / \mathrm{Co}$ and $\mathrm{Fe} / \mathrm{Co}$ ratios, and lack of correlation of those ratios with Co, $\mathrm{Ce}$, and $\mathrm{Ce} / \mathrm{Co}$, indicate that the ANS Fe-Mn crusts are distinct from Pacific seamount $\mathrm{Fe}-\mathrm{Mn}$ crusts, and reflect region-specific chemical characteristics. The platinum group elements (PGE: Ir, $\mathrm{Ru}, \mathrm{Rh}, \mathrm{Pt}$, and $\mathrm{Pd}$ ) and $\mathrm{Au}$ in $\mathrm{ANS} \mathrm{Fe}-\mathrm{Mn}$ crusts are derived from seawater and are mainly of terrestrial origin, with a minor cosmogenic component. The $\mathrm{Ru} / \mathrm{Rh}(0.5-2)$ and $\mathrm{Pt} / \mathrm{Ru}$ ratios (7-28) are closely comparable to ratios in continental basalts, whereas $\mathrm{Pd} / \mathrm{Ir}$ ratios exhibit values $(<2)$ similar to CI-chondrite $(\sim 1)$. The chondrite-normalized PGE patterns are similar to those of igneous rocks, except that $\mathrm{Pd}$ is relatively depleted. The water depth of $\mathrm{Fe}-\mathrm{Mn}$ crust formation appears to have a first-order control on both major element and PGE enrichments. These relationships are defined statistically by significant $(r>0.75)$ correlations between water depth and $\mathrm{Mn} / \mathrm{Co}, \mathrm{Fe} / \mathrm{Co}, \mathrm{Ce} / \mathrm{Co}, \mathrm{Co}$, and the PGEs. Fractionation of the PGE-Au from seawater during colloidal precipitation of the major-oxide phases is indicated by well-defined linear positive correlations $(r>0.8)$ of $\mathrm{Co}$ and $\mathrm{Ce}$ with $\mathrm{Ir}, \mathrm{Ru}, \mathrm{Rh}$, and $\mathrm{Pt}$; $\mathrm{Au} / \mathrm{Co}$ with $\mathrm{Mn} / \mathrm{Co}$; and by weak or no correlations of $\mathrm{Pd}$ with water depth, Co-normalized major-element ratios, and with the other PGE $(r<0.5)$. The strong enrichment of Pt (up to $1 \mathrm{ppm}$ ) relative to the other PGE and its positive correlations with Ce and Co demonstrate a common link for the high concentrations of all three elements, which likely involves an oxidation reaction on the Mn-oxide and Fe-oxyhydroxide surfaces. The documented fractionation of PGE-Au and their positive association with redox sensitive Co and Ce may have applications in reconstructing past-ocean redox conditions and water masses.
\end{abstract}

\section{Introduction}

Central Pacific seamount ferromanganese crusts (Fe-Mn crust) enrich Co up to $2 \%$ and Pt up to $3 \mathrm{ppm}$ (Halbach et al 1989a and b; Usui and Someya 1997). In addition to Pt, the other PGE $(\mathrm{Ru}, \mathrm{Rh}, \mathrm{Ir}$, and $\mathrm{Pd})$ as well as $\mathrm{Au}$ are enriched many-fold compared to their concentrations in seawater from which the $\mathrm{Fe}-\mathrm{Mn}$ crusts precipitated
(Hein et al 2000; Palmer and Turekian 1986). Hein et al (2000) showed that Pt, Rh, and Ir are derived from seawater, whereas $\mathrm{Pd}$ is hosted mostly in detrital minerals, which are intimately mixed with $\mathrm{Fe}-\mathrm{Mn}$ oxide minerals in Fe-Mn crust. Although PGE is a group of coherent siderophile metals, they generally do not exhibit good coherency in many marine systems because of their fractionation by several oceanographic and geochemical processes

Keywords. Indian Ocean; ferromanganese crusts; platinum group elements; source and fractionation. 
such as their efficiency of formation of complexes and adsorption to host phases under variable redox conditions in ambient water (Sawlowicz 1993; Hodge et al 1985).

The PGE gained importance after the discovery of Ir anomaly associated with the CretaceousTertiary (KT) boundary mass-extinction that resulted from a catastrophic bolide impact (Alvarez et al 1980). Subsequently, studies exploring the potential use of PGE as indicators of large-scale alteration of Earth's atmosphere, and in turn of ecosystems, have been discussed based on continental and marine sedimentary sequences across the KT boundary (e.g., Lee et al 2003). Anomalous PGE concentrations in several sedimentary deposits, however, are not associated with global mass extinction and alternative mechanisms, such as volcanic input, diagenesis, authigenic precipitation from seawater, among others, have been proposed (e.g., see Colodner et al 1992; Strong et al 1987). The PGE chemistry of seawater can be better understood from studying hydrogenetically precipitated Coenriched $\mathrm{Fe}-\mathrm{Mn}$ crusts deposited on open-ocean seamounts where diagenetic and hydrothermal metal inputs are uncommon. However, PGE studies of marine hydrogenetic and authigenic deposits are few.

Previous studies of PGE in Fe-Mn crusts mostly focused on the mechanism of Pt enrichment (see Halbach et al 1989a, 1989b) because Pt adds to the potential economic value of the deposits (Hein et al 2000). Here, we present the first PGE and Au data for Fe-Mn crusts occurring on ANS and discuss aspects related to their fractionation and dominant sources. The ANS is thought to have formed during the Late Cretaceous (Sborshchikov et al 1995) and shows convincing evidence of subaerial weathering followed by submergence (Banakar et al 1997). The ANS attained its present configuration around Late Miocene as indicated by the continuous growth of $\mathrm{Fe}-\mathrm{Mn}$ crusts over conglomeritic substrate rocks containing rounded basalt clasts and brachiopod casts embedded in neomorphic carbonate cement (Banakar et al 1997). The Fe-Mn crusts from this seamount show Co and Ce enrichments up to $0.9 \%$ and $0.4 \%$, respectively (Rajani et al 2005). Because Fe-Mn crust composition changes in response to long-term variations in oceanographic conditions and continental erosion (see Banakar and Hein 2000; Banakar et al 2003 and references therein), the present study provides useful clues for understanding PGE anomalies in the marine environment. However, the relative importance of each mechanism is difficult to quantify using bulk Fe-Mn crust (i.e., total $\mathrm{Fe}-\mathrm{Mn}$ oxide layer excluding substrate rock) PGE dataset.

\section{Material and methods}

Fe-Mn crusts were recovered by dredging along short tracks of $\sim 100 \mathrm{~m}$ on the slopes of ANS during two cruises of the R. V. A A Sidorenko (AAS-59 and AAS-65: February and August 2003 respectively), undertaken for exploration of Coenriched seamount $\mathrm{Fe}-\mathrm{Mn}$ crusts in the EEIO. Most ANS volcanic peaks hosting Fe-Mn crusts rise from a large plateau at $\sim 3.2 \mathrm{~km}$ water depth that extends $\sim 400 \mathrm{~km}$ north-south and $\sim 250 \mathrm{~km}$ east-west at $\sim 3^{\circ} \mathrm{S}$ latitude and $\sim 83^{\circ} \mathrm{E}$ longitude (figure 1). The base of the ANS is at $\sim 4.5 \mathrm{~km}$ water depth. The thickness of $\mathrm{Fe}-\mathrm{Mn}$ oxide layer varies from a coating to $\sim 7 \mathrm{~cm}$. Fe-Mn crusts were collected from water depths ranging from $1.6 \mathrm{~km}$ (top of the highest peak) to $3.2 \mathrm{~km}$ (top of the plateau). Fe-Mn crusts were not recovered from $3.2 \mathrm{~km}$ (top of the plateau) to $4.5 \mathrm{~km}$ (base of the seamount or surrounding seafloor). Carbonate sedimentation on plateau and lower flanks of the seamount may be the reason for absence of $\mathrm{Fe}-\mathrm{Mn}$ crusts here. Thus sedimentation may have prevented the growth of Fe-Mn crusts on plateau and basal slopes. We recovered samples of $\mathrm{Fe}-$ Mn crusts in over 25 dredge hauls from different depths and selected nine representative samples for this study, for which $\mathrm{Mn}$, Fe, Co, Ce, PGE, and $\mathrm{Au}$ data were obtained. Only those $\mathrm{Fe}-\mathrm{Mn}$ crust samples having a $>2 \mathrm{~cm}$-thick oxide layer with $\mathrm{Mn}$ and Fe contents each $>14 \%$ were used in order to limit this study to samples with minimum dilution by non-hydrogenetic components, such as carbonate and silicate detritus.

The Fe-Mn oxide layer was chipped off the substrate rocks and ground to fine powder (-200 mesh). Powdered samples were oven dried at $\sim 110^{\circ} \mathrm{C}$ overnight and aliquots were used for the various measurements. The Fe, $\mathrm{Mn}, \mathrm{Co}$, and $\mathrm{Ce}$ concentrations were measured on $6 \mathrm{~N} \mathrm{HCl}$ leachates using a Perkin-Elmer ${ }^{\circledR}$ OPTIMA-2000 DV ICPOES. PGE and $\mathrm{Au}$ were measured by both $\mathrm{Ni}-$ and Pb-fire assay with an ICP-MS finish at the U.S. Geological Survey (Baedecker 1987). For Nisulfide, the sample powder $(\sim 15 \mathrm{~g})$ was mixed with a flux prepared from soda ash, borax, silica, sulfur, and nickel carbonate and fused at $1200^{\circ} \mathrm{C}$. During fusion, $\mathrm{Ni}, \mathrm{PGE}$, and $\mathrm{Au}$ sulfides were formed. The fused mixture was treated with $\mathrm{HCl}$ in which the Ni sulfide was dissolved and removed. The remainder, containing PGE and $\mathrm{Au}$, was dissolved in aquaregia in a borosilicate test tube and diluted with nitric acid to the required volume for measurement. A control blank was run before and after the sample run and each blank value was below the detection limits of $5 \mathrm{ppb}$ for $\mathrm{Au} ; 2 \mathrm{ppb}$ for $\mathrm{Ir}, \mathrm{Os}, \mathrm{Pd}, \mathrm{Pt}$, and $\mathrm{Ru}$; and $1 \mathrm{ppb}$ for Rh. Repeat analysis of reference standards SRM7b yielded, 


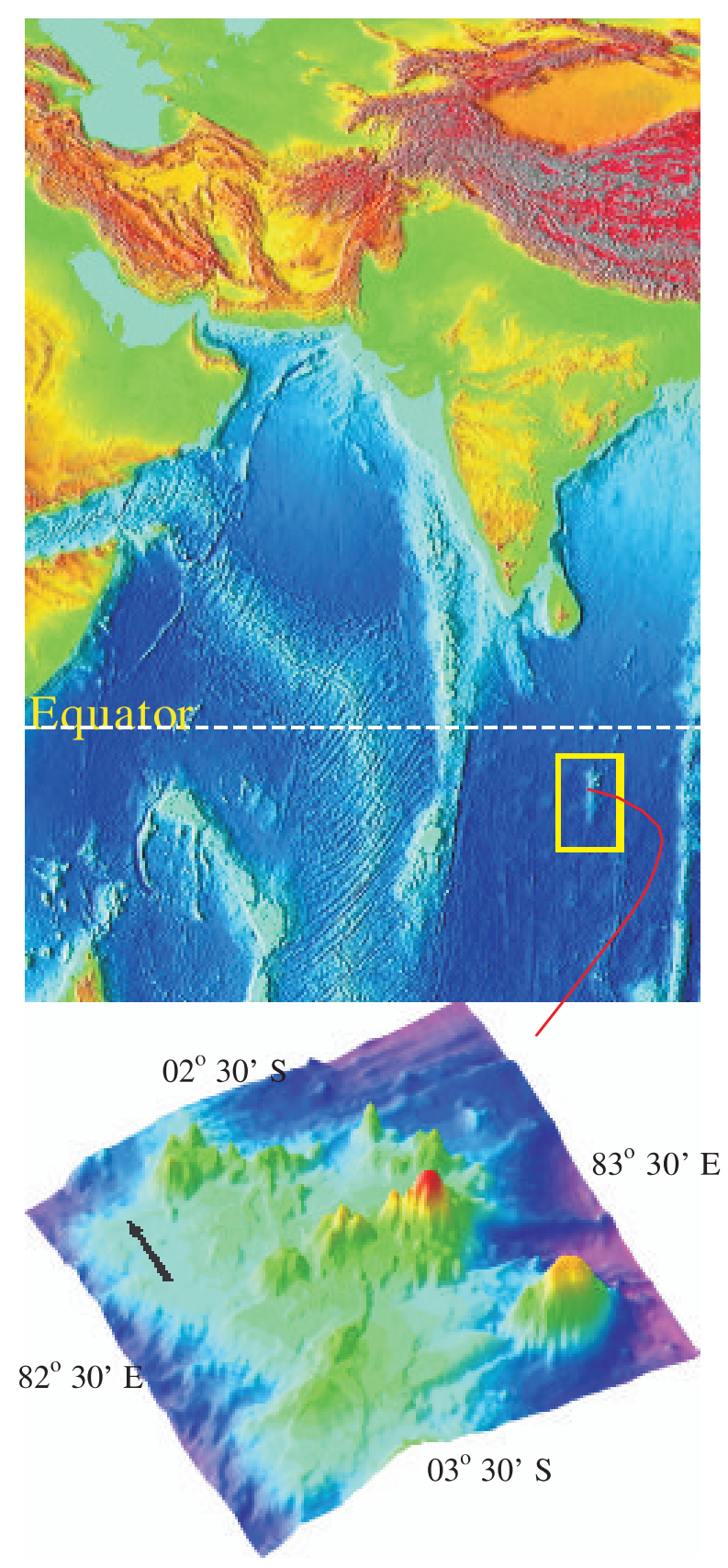

Figure 1. Location of the Afanasiy-Nikitin seamount (enclosed by box) in the Indian Ocean (www.ngdc.noaa). Location details are given in the text. The lower panel is vertically exaggerated $3-\mathrm{D}$ colour coded multibeam swath-bathymetric map of northern part of the seamount $(100 \times 100 \mathrm{~km})$ generated on board R. V. Boris Petrov in March 2005. The samples are from two transects (approximately east-west and north-south) across the central cluster of mounts. Pink colour indicates deepest $(>4500 \mathrm{~m})$ region and red colour indicates shallowest $(<1700 \mathrm{~m})$ region. Arrow on the lower panel indicates north specific only to the lower panel.

Ir $85 \mathrm{ppb}$, Os $59 \mathrm{ppb}, \mathrm{Pd} 1352 \mathrm{ppb}$, Pt $3617 \mathrm{ppb}$, $\mathrm{Rh} 224 \mathrm{ppb}, \mathrm{Ru} 424 \mathrm{ppb}$ and $\mathrm{Au} 271 \mathrm{ppb}$ as against the Mintek certified values of $90 \mathrm{ppb}, 63 \mathrm{ppb}$, $1540 \mathrm{ppb}, 3740 \mathrm{ppb}, 240 \mathrm{ppb}, 460 \mathrm{ppb}$ and $270 \mathrm{ppb}$ respectively. Thus the accuracy of the data presented here is better than $\pm 10 \%$. Analytical precision was better than $20 \%$ for $\mathrm{Au}$, Ir, and $\mathrm{Pd}, 10 \%$ for $\mathrm{Rh}$, and $5 \%$ for $\mathrm{Ru}$ and $\mathrm{Pt}$. Os was less than its detection limit (2ppb) for all but one sample (ADR 27), which has $4 \mathrm{ppb}$. Ag was measured by atomic absorption spectrometry, but concentrations were less than the detection limit of $1 \mathrm{ppm}$ in all samples. Hence, Os and Ag will not be discussed further. As the $\mathrm{Au}$ concentration in $\mathrm{Fe}-\mathrm{Mn}$ crusts never falls to zero, we multiplied its concentration at detection limit ( $5 \mathrm{ppb}$ ) by 0.5 for statistical analysis. The PGE in few duplicate samples were also measured at the ICP-MS facility of National Geophysical Research Institute, India, following the same procedures of sample preparation (see Balaram et al 2005), and the results from both the laboratories are comparable within $\pm 10 \%$ for high concentration PGE (Pt, Ru, Rh) and within $\pm 20 \%$ for low concentration PGE (Pd, Ir) and Au.

\section{Results and discussion}

The dominant elements in ANS Fe-Mn crusts, $\mathrm{Mn}$ and $\mathrm{Fe}$, vary between $14 \%$ and $25 \%$, followed by Co $(0.35 \%$ to $0.85 \%)$ and Ce $(0.09 \%$ to $0.24 \%$ ) (table 1). Data for $\mathrm{Si}, \mathrm{Al}$, and $\mathrm{Ti}$ are not available. However, those elements typically occur in concentrations higher than $\mathrm{Co}$ and $\mathrm{Ce}$ as they are mostly associated with silicate detritus, which is the second abundant component after $\mathrm{Fe}-\mathrm{Mn}$ oxide. However, Ti can have a significant hydrogenetic component (Koschinsky and Halbach 1995). The generally observed correlation of Co with $\mathrm{Mn}$ and $\mathrm{Ce}$ with $\mathrm{Fe}$ in seamount $\mathrm{Fe}-\mathrm{Mn}$ crusts (e.g., Banakar and Hein 2000; De Carlo and McMurtry 1992; Halbach et al 1989b; Hein et al 2000; Koschinsky and Hein 2003) does not occur in the ANS Fe-Mn crust data set (table 2). Such correlations led Rajani et al (2005) to hypothesize the independent precipitation of Co and Ce oxides. This hypothesis needs to be tested by EXAFS or XANES analyses of the oxide phases. We discuss this possibility in a later section by examining correlations obtained from Co-normalized element ratios. Elements are normalized to Co because it has a nearly constant flux from seawater and is almost solely of hydrogenetic origin.

The subequal amounts of $\mathrm{Fe}$ and $\mathrm{Mn}(\mathrm{Mn} / \mathrm{Fe}$ 0.94-1.27) in the ANS Fe-Mn crusts indicate a hydrogenetic origin and an absence of hydrothermal input (Hein et al 2000; Banakar et al 1997). Therefore, PGE-enrichment processes from hydrothermal activity (Halbach et al 1989b; Koide et al 1991; Officer and Drake 1985) may not have contributed to the PGE and Au concentrations of ANS Fe-Mn crusts. Substrate rocks neither 
Table 1. Major element, PGE-Au and cobalt normalized element ratio of Afanasiy-Nikitin seamount Fe-Mn crusts compared with potential source material.

\begin{tabular}{|c|c|c|c|c|c|c|c|c|}
\hline Sample code & Depth & $\mathrm{Mn}^{*}$ & $\mathrm{Fe}^{*}$ & $\mathrm{Co}^{*}$ & $\mathrm{Ce}^{*}$ & $\operatorname{lr}^{* *}$ & $\mathrm{Ru}^{* *}$ & $\mathrm{Rh}^{* *}$ \\
\hline $\mathrm{CC} 1 / \mathrm{DR} 25$ & 1.75 & $15.5(20)$ & $16.0(21)$ & 0.77 & $0.29(0.4)$ & $14(1.8)$ & $31(4.0)$ & $48(6.2)$ \\
\hline CC1/DR12B & 1.91 & $18.0(24)$ & $14.2(19)$ & 0.75 & $0.26(0.3)$ & 08(1.1) & $24(3.2)$ & $24(3.2)$ \\
\hline CC2/ADR19 & 2.00 & $22.0(30)$ & $19.3(26)$ & 0.74 & $0.24(0.3)$ & $09(1.2)$ & $20(2.7)$ & $38(5.1)$ \\
\hline $\mathrm{CC} 2 / \mathrm{ADR} 27$ & 2.06 & $24.9(29)$ & $24.2(28)$ & 0.85 & $0.19(0.2)$ & $10(1.2)$ & $31(3.6)$ & $23(2.7)$ \\
\hline $\mathrm{CC} 2 / \mathrm{ADR} 26$ & 2.10 & $19.6(47)$ & $19.2(46)$ & 0.42 & $0.09(0.2)$ & $03(0.7)$ & $12(2.9)$ & $06(1.4)$ \\
\hline CC2/ADR11 & 2.20 & $18.7(32)$ & $19.5(33)$ & 0.59 & $0.13(0.2)$ & $06(1.0)$ & $17(2.9)$ & $13(2.2)$ \\
\hline CC2/ADR10 & 2.62 & $18.1(33)$ & $19.2(35)$ & 0.55 & $0.12(0.2)$ & $06(1.1)$ & $17(3.1)$ & $13(2.4)$ \\
\hline CC2/ADR4 & 3.15 & $20.9(47)$ & $20.2(46)$ & 0.44 & $0.14(0.3)$ & $05(1.1)$ & $15(3.4)$ & $10(2.3)$ \\
\hline CC2/ADR24 & 3.20 & $22.2(63)$ & $22.6(65)$ & 0.35 & $0.13(0.4)$ & $04(1.1)$ & $12(3.4)$ & $07(2.0)$ \\
\hline \multicolumn{6}{|c|}{ CI Chondrite (Anders and Ebihara 1982) } & 473 & 714 & 134 \\
\hline \multicolumn{6}{|c|}{ Iron meteorite (Crocket 1972) } & 4 & 73 & na \\
\hline \multicolumn{6}{|c|}{ Karoo basalt (Naldrett 1981) } & 88 & 147 & 80 \\
\hline \multicolumn{6}{|c|}{ Duluth basalt (Naldrett 1981) } & 6 & 15 & 16 \\
\hline \multicolumn{6}{|c|}{ Deccan basalt (Crocket and Paul 2004) } & 0.024 & na & na \\
\hline \multicolumn{6}{|c|}{ Carbonate ooze (Hodge et al 1985) } & na & na & na \\
\hline \multicolumn{6}{|c|}{ Siliceous ooze (Hodge et al 1985) } & na & na & na \\
\hline \multicolumn{6}{|c|}{ Ultramafic rocks (Crocket 1981) } & 3.8 & 6.1 & 3 \\
\hline \multicolumn{6}{|c|}{ Black shale-Chine (Coveney et al 1992) } & 0.1 & 16 & na \\
\hline \multicolumn{6}{|c|}{ Continental crust (Govett 1983) } & 1 & na & 1 \\
\hline \multicolumn{6}{|c|}{ MORB-Pacific (Peucker-Ehrenbrink et al 2003) } & 0.01 & na & na \\
\hline \multicolumn{6}{|c|}{ MORB-Atlantic (Peucker-Ehrenbrink et al 2003) } & 0.03 & 0.7 & na \\
\hline
\end{tabular}

Depth in km; $\quad{ }^{*}$ - wt. \%; $\quad{ }^{* *}-$ ppb; Values in parentheses are Element/Cobalt ratio $\left(\mathrm{X} 10^{\mathrm{b}}\right)$; na - not available. All values are rounded to nearest decimal. All Ag and Os concentrations are below detection limit.

$\$$ - estimated values (see text).

provide fluids that contribute to the formation of $\mathrm{Fe}-\mathrm{Mn}$ crusts nor diagenetically influence their composition (Banakar and Hein 2000; Hein and Morgan 1999).

The sources of PGE and $\mathrm{Au}$ in seawater are terrestrial and cosmogenic inputs and these elements occur in both dissolved and particulate forms (Halbach et al 1989a; Hein et al 2005). The detrital component in seamount $\mathrm{Fe}-\mathrm{Mn}$ crusts is largely derived from erosion of continental crust and from input of local volcanogenic minerals. Average continental crust contains very low PGE-Au concentrations (Kyte and Wasson 1986). Most of the silicate detritus reaching the ANS region is derived from Himalayan erosion with insignificant contributions from peninsular Indian basalts, hence detrital input cannot be the dominant host for noble metals in these $\mathrm{Fe}-\mathrm{Mn}$ crusts. Therefore, the PGE in these $\mathrm{Fe}-\mathrm{Mn}$ crusts must be considered as having been derived predominantly from seawater.

\subsection{Sources for and incorporation of $P G E-A u$ in $\mathrm{Fe}-\mathrm{Mn}$ crusts}

The PGE contents in seawater are extremely low: Ir, 0.0013 ppt (Hodge et al 1986); Ru, $\sim 0.002 \mathrm{ppt} \quad$ (Goldberg 1987); Rh, $\sim 0.09 \mathrm{ppt}$
(Bertine et al 1993); Pt, 0.2 to $1 \mathrm{ppt}$ (Goldberg et al 1986; Turretta et al 2003), and $\mathrm{Pd}, \sim 0.04 \mathrm{ppt}$ (Goldberg 1987). Their enrichment in the ANS $\mathrm{Fe}-\mathrm{Mn}$ crusts over seawater values is about $10^{4}$ to $10^{7}$ times. However, this enrichment is $2-3$ orders of magnitude lower than the enrichment of the most dominant elements, such as transition and rare earth elements (see Hein et al 2003, 2005). On a global scale, the PGE are fractionated twice, once during weathering and transfer to seawater, where the order of decreasing abundance changes from Pt-Pd-Ru-Rh-Ir to Pt-Rh-Pd-Ru-Ir; and a second time during incorporation from seawater into $\mathrm{Fe}-\mathrm{Mn}$ crusts where the order of abundance then changes to Pt-Ru-Rh-Ir-Pd (Hein et al 2005).

The uptake of PGE and $\mathrm{Au}$ in $\mathrm{Fe}-\mathrm{Mn}$ crusts is not fully understood and the pathways of PGE and $\mathrm{Au}$ in marine biogeochemical processes are still largely unknown. Halbach et al (1989a, 1989b) proposed co-precipitation of $\mathrm{Pt}$ with $\mathrm{Mn}$ oxide due to coupled redox reactions in addition to input of cosmic dust as the causes of Pt enrichment in Pacific seamount Fe-Mn crusts. Hein et al (2003) suggested that $\mathrm{Pt}$ is sorbed and then oxidized on the surface of the FeOOH phase, similar to the mechanism that may strongly enrich Te in $\mathrm{Fe}-\mathrm{Mn}$ crusts. Vonderhaar et al (2000) suggested that Pt 
Table 1. (Continued)

\begin{tabular}{|c|c|c|c|c|c|c|c|c|c|}
\hline $\mathrm{Pt}^{* *}$ & $\mathrm{Pd}^{* *}$ & $\mathrm{Au}^{* *}$ & $\mathrm{Pt} / \mathrm{Pd}$ & $\mathrm{Ru} / \mathrm{Rh}$ & $\mathrm{Pd} / \mathrm{lr}$ & $\mathrm{Pt} / \mathrm{lr}$ & $\mathrm{Pd} / \mathrm{Ru}$ & $\mathrm{Pt} / \mathrm{Ru}$ & $\mathrm{Pt} / \mathrm{Au}$ \\
\hline $780(101)$ & $04(0.5)$ & $2.5(0.3)^{\$}$ & 195 & 0.65 & 0.29 & 55.7 & 0.13 & 25.2 & 312 \\
\hline $357(48)$ & $03(0.4)$ & $2.5(0.3)^{\$}$ & 119 & 1.00 & 0.38 & 44.6 & 0.13 & 14.9 & 143 \\
\hline $568(77)$ & $08(1.1)$ & $13(1.8)$ & 71 & 0.53 & 0.89 & 63.1 & 0.40 & 28.4 & 43.7 \\
\hline $286(34)$ & $20(2.3)$ & $18(2.1)$ & 14 & 1.35 & 2.00 & 28.6 & 0.65 & 9.2 & 15.9 \\
\hline $102(24)$ & $06(1.4)$ & $15(3.6)$ & 17 & 2.00 & 2.00 & 34.0 & 0.50 & 8.5 & 6.8 \\
\hline $166(28)$ & $06(1.0)$ & $11(1.9)$ & 28 & 1.31 & 1.00 & 27.7 & 0.35 & 9.8 & 15.1 \\
\hline $149(27)$ & $05(0.9)$ & $07(1.3)$ & 30 & 1.31 & 0.83 & 24.8 & 0.29 & 8.8 & 21.3 \\
\hline $111(25)$ & $08(1.8)$ & $13(2.9)$ & 14 & 1.50 & 1.60 & 22.2 & 0.53 & 7.4 & 8.5 \\
\hline $101(29)$ & $04(1.1)$ & $19(5.4)$ & 25 & 1.71 & 1.00 & 25.3 & 0.33 & 8.4 & 5.3 \\
\hline 953 & 557 & 145 & 1.71 & 5.33 & 1.18 & 2 & 0.78 & 1.3 & 6.6 \\
\hline 9.4 & 4.5 & 1.3 & 2.09 & & 1.13 & 2.4 & 0.62 & 1.3 & 7.2 \\
\hline 1330 & 708 & 397 & 1.88 & 1.84 & 8.05 & 15.1 & 4.8 & 9 & 3.4 \\
\hline 333 & 1113 & 147 & 0.3 & 0.94 & 186 & 55.5 & 74.2 & 22.2 & 2.3 \\
\hline 4.2 & 13 & 4.3 & 0.3 & & 554 & 175 & & & 1.0 \\
\hline 3 & 1.6 & na & 1.88 & & & & & & \\
\hline 2.3 & 3.6 & na & 0.64 & & & & & & \\
\hline 9.1 & 6.7 & na & 1.36 & 2.03 & 1.76 & 2.4 & 1.1 & 1.5 & \\
\hline 15 & 37 & 48 & 0.41 & & 370 & 150 & 2.31 & 0.9 & 0.3 \\
\hline 5 & 10 & 4 & 0.5 & & 10 & 5 & & & 1.3 \\
\hline 0.3 & 0.27 & na & 1.11 & & 27 & 30 & & & \\
\hline 0.8 & 2 & na & 0.4 & & 67 & 27 & 2.86 & 1.1 & \\
\hline
\end{tabular}

enrichment is closely tied to the diagenetic formation of carbonate flourapatite in central Pacific $\mathrm{Fe}-\mathrm{Mn}$ crusts. Diverse mechanisms of PGE enrichment in marine sediments have also been suggested, ranging from microbial activity to cosmic dust (see Sawlowcz 1993).

Compared to CI-Chondrites (Anders and Ebihara 1982), ANS Fe-Mn crusts are depleted in PGE-Au, but are significantly enriched compared to pelagic sediment (Esser and Turekian 1988) (table 1). Although the average continental crust is highly depleted in PGE-Au (Crocket and Kuo 1979), continental basalts show considerable enrichments (Crocket 1981; Crocket and Paul 2004; Naldrett 1981), nearly of the magnitude found in ANS Fe-Mn crusts (table 1). However, PGE variations in different basalts are large, as evident from the Karoo, Duluth, and Deccan basalts (table 1). Nevertheless, cosmogenic debris and plateau basaltic rocks (large igneous complexes) may be important sources of seawater PGE-Au.

Chondrite-normalized PGE patterns of ANS $\mathrm{Fe}-\mathrm{Mn}$ crusts are closely comparable for the entire water-depth range (figure 2). They demonstrate the consistent $\mathrm{Pt}$ enrichment over other PGEs. The anomalous enrichment of $\mathrm{Pt}$ over $\mathrm{Pd}$ in marine $\mathrm{Fe}-\mathrm{Mn}$ nodules and crusts (Pt/Pd, 50-1000) compared to seawater ratios $(\sim 4-5)$ was recognized by
Hodge et al (1985). They proposed oxidation of $\mathrm{Pt}$ from the dissolved pool, similar to Ce and Co, to explain its several orders of magnitude enrichment in $\mathrm{Fe}-\mathrm{Mn}$ nodules and crusts. The PGE patterns from Ir to Pt in ANS Fe-Mn crusts are similar to their fractionation patterns in terrestrial magmas, which exhibit fractionation in the order of decreasing melting points (Barnes et al 1985). This observation is of interest because the lowest melting point is for $\mathrm{Pd}$, which apparently fractionates last during magmatic crystallization (Barnes et al 1985), but shows depletion relative to the other chondrite-normalized PGE in ANS Fe-Mn crusts. This anomalous depletion of $\mathrm{Pd}$ suggests that it was decoupled from the other PGE at the source before reaching the oceanic reservoir, if continental crust was their main source. Further, if the oceanic reservoir of PGE is the result of weathering input from continental rocks, then their relative abundances should reflect their mobility during low temperature chemical weathering, which would also follow igneous fractionation trend. The lower melting point PGE (e.g., Pd) is fractionated from the igneous rock more readily than the higher melting point PGE (e.g., Ru). This weathering fractionation pattern may be overprinted if there are other significant sources not governed by magmatic crystallization, such as the weathering of PGE-rich 

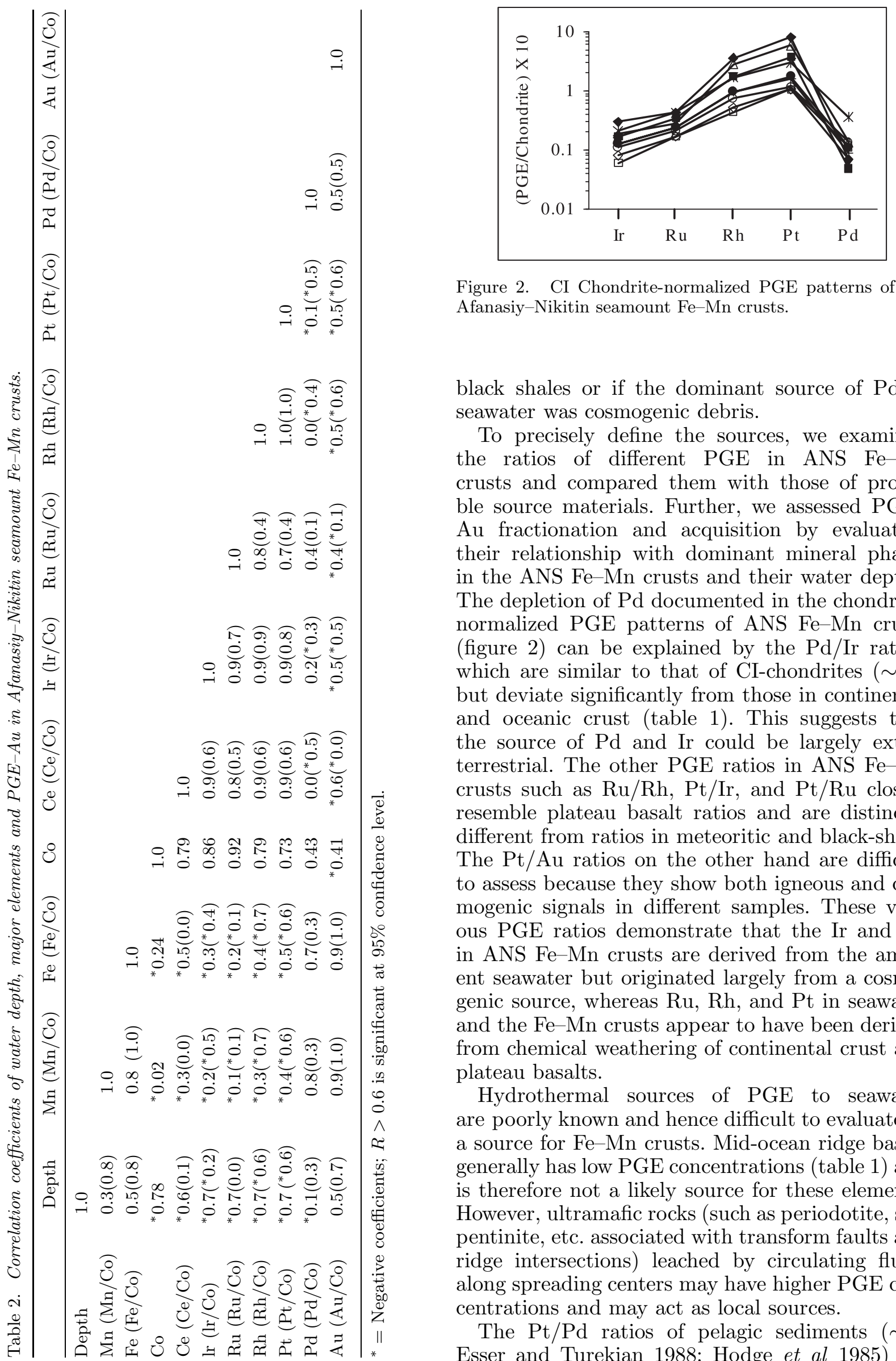

Figure 2. CI Chondrite-normalized PGE patterns of the Afanasiy-Nikitin seamount Fe-Mn crusts.

black shales or if the dominant source of $\mathrm{Pd}$ in seawater was cosmogenic debris.

To precisely define the sources, we examined the ratios of different $\mathrm{PGE}$ in ANS $\mathrm{Fe}-\mathrm{Mn}$ crusts and compared them with those of probable source materials. Further, we assessed PGE$\mathrm{Au}$ fractionation and acquisition by evaluating their relationship with dominant mineral phases in the ANS Fe-Mn crusts and their water depths. The depletion of $\mathrm{Pd}$ documented in the chondritenormalized PGE patterns of ANS Fe-Mn crusts (figure 2) can be explained by the $\mathrm{Pd} / \mathrm{Ir}$ ratios, which are similar to that of CI-chondrites $(\sim 1)$, but deviate significantly from those in continental and oceanic crust (table 1). This suggests that the source of $\mathrm{Pd}$ and Ir could be largely extraterrestrial. The other PGE ratios in ANS Fe-Mn crusts such as $\mathrm{Ru} / \mathrm{Rh}, \mathrm{Pt} / \mathrm{Ir}$, and $\mathrm{Pt} / \mathrm{Ru}$ closely resemble plateau basalt ratios and are distinctly different from ratios in meteoritic and black-shale. The $\mathrm{Pt} / \mathrm{Au}$ ratios on the other hand are difficult to assess because they show both igneous and cosmogenic signals in different samples. These various PGE ratios demonstrate that the Ir and Pd in ANS $\mathrm{Fe}-\mathrm{Mn}$ crusts are derived from the ambient seawater but originated largely from a cosmogenic source, whereas $\mathrm{Ru}, \mathrm{Rh}$, and $\mathrm{Pt}$ in seawater and the $\mathrm{Fe}-\mathrm{Mn}$ crusts appear to have been derived from chemical weathering of continental crust and plateau basalts.

Hydrothermal sources of PGE to seawater are poorly known and hence difficult to evaluate as a source for $\mathrm{Fe}-\mathrm{Mn}$ crusts. Mid-ocean ridge basalt generally has low PGE concentrations (table 1) and is therefore not a likely source for these elements. However, ultramafic rocks (such as periodotite, serpentinite, etc. associated with transform faults and ridge intersections) leached by circulating fluids along spreading centers may have higher PGE concentrations and may act as local sources.

The $\mathrm{Pt} / \mathrm{Pd}$ ratios of pelagic sediments $(\sim 5$ : Esser and Turekian 1988; Hodge et al 1985) are 

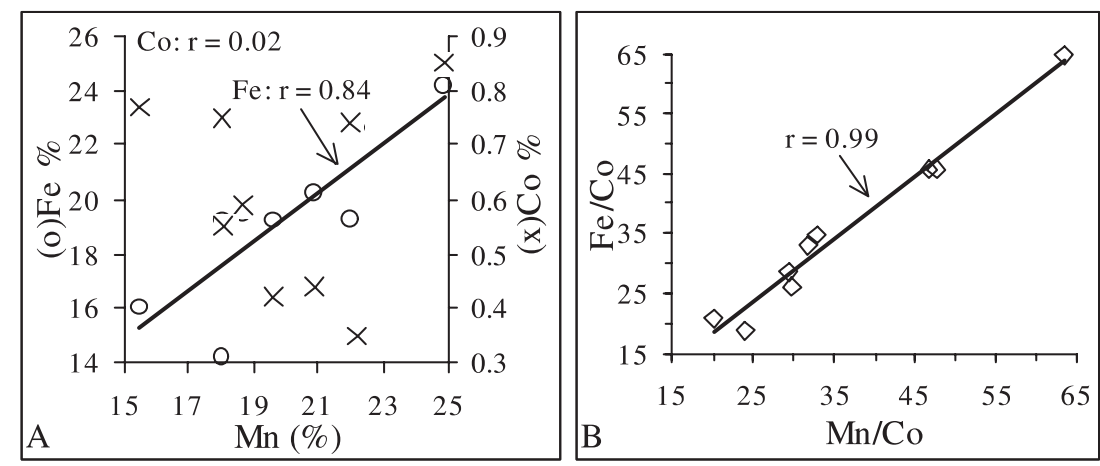

Figure 3. Fe and Mn relationship in the Afanasiy-Nikitin seamount Fe-Mn crusts (A) showing significant improvement in association after normalizing with Co (B). The positive correlation between Fe and Mn and lack of correlation between $\mathrm{Mn}$ and $\mathrm{Co}$ are atypical of crusts studied elsewhere.

similar to the mean seawater ratio of $\sim 4.5$ (Hodge et al 1985). In contrast, ANS Fe-Mn crusts and other ocean $\mathrm{Fe}-\mathrm{Mn}$ deposits show significantly higher $\mathrm{Pt} / \mathrm{Pd}$ ratios $(\geq 100)$ than do pelagic sediments. These ratios suggest high efficiency for $\mathrm{Pt}$ acquisition by marine $\mathrm{Fe}-\mathrm{Mn}$ deposits compared to pelagic sediments, which are affected by diagenetic processes.

\subsection{Major element-phases and water-depth associations}

We obtained best fits for scatter plots of major elements and PGE-Au data to understand how PGE and $\mathrm{Au}$ are fractionated in the ANS Fe-Mn crusts. Several oceanographic and geochemical processes dictate the composition of $\mathrm{Fe}-\mathrm{Mn}$ crusts (Frank et al 1999), where water depth being an important parameter. Therefore, more fundamental chemical associations between various components of the crusts can be determined by eliminating the effects of water depth, accretion rate, and temporal changes in seawater chemistry. Normalizing the chemical data to an element that has a constant flux in space and time to the Fe-Mn crusts can approximate that ideal condition. The flux of $\mathrm{Co}$ to $\mathrm{Fe}-\mathrm{Mn}$ crusts is thought to be constant $\left(2.9 \mu \mathrm{g} / \mathrm{cm}^{2} \cdot \mathrm{ka}\right)$ at all water depths over large time-spans, of several millions of years, as determined for Pacific seamount Fe-Mn crusts (Halbach et al 1983). Hence, Co-normalized element ratios may provide a better understanding of the chemical associations between the elements than those obtained from element concentration data. Both linear and non-linear relationships between major components and $\mathrm{PGE}-\mathrm{Au}$ are evident (table 2 and figures 3-5), which demonstrate that the element enrichment processes are complex in $\mathrm{Fe}-\mathrm{Mn}$ crusts. We looked for coherence in data distribution in the scatter plots and calculated $r$-values of the linear best-fits obtained for concentration and
Co-normalized data (table 2). Only those linear relationships with $r$-values $<0.7$ (at 95\% confidence level) were subjected to non-linear trend analysis. We are aware of the limitation due to statistically small number of samples $(n=9)$ and hence the documented relationships and interpretations need further refinements based on larger dataset.

Strong positive correlations between $\mathrm{Mn}$ and Fe and between $\mathrm{Mn} / \mathrm{Co}$ and $\mathrm{Fe} / \mathrm{Co}(r=0.84$ and 0.99 , respectively; table 2 and figure 3 ) contrast with generally observed inverse relationships in Pacific Fe-Mn crusts (Wen et al 1997 and references therein). Interestingly, Co is not correlated with $\mathrm{Mn}$ or Fe $(r<0.2$; table 2 and figure 3$)$, but shows a strong positive correlation with $\mathrm{Ce}(r=0.8$; table 2). These remarkable differences compared to $\mathrm{Fe}-\mathrm{Mn}$ crusts studied elsewhere suggest that the compositional characteristics of the ANS Fe-Mn crusts are region specific (Rajani et al 2005).

Co concentrations vary inversely with water depth $(r=-0.78$; table 2 and figure $3 \mathrm{~A})$, whereas $\mathrm{Ce}$ and $\mathrm{Ce} / \mathrm{Co}$ exhibit strong non-linear variations with water depth $(r=0.86$ and 0.91 ; figure $4 \mathrm{~A}$ and $4 \mathrm{~B})$, where trend reversal begins at $\sim 2 \mathrm{~km}$ water depth. The linear inverse correlation of Co with water depth is well known (Halbach et al 1983), but the association of $\mathrm{Ce}$ and $\mathrm{Ce} / \mathrm{Co}$ with water depth is opposite to that documented by Aplin (1984), who reported higher Ce contents in Fe-Mn crusts above $2000 \mathrm{~m}$ water depth in the Central Pacific. Our data can be interpreted to indicate (1) rapid removal of $\mathrm{Ce}$ to the $\mathrm{Fe}-\mathrm{Mn}$ crusts in the upper $\sim 2 \mathrm{~km}$ of the water column; (2) slower growth rates for crusts above $\sim 2 \mathrm{~km}$, or (3) a different source of $\mathrm{Ce}$ in the water mass below $\sim 2 \mathrm{~km}$. This approximately $2 \mathrm{~km}$ divide is clearly evident by a two-fold enrichment of Ce in samples above $\sim 2 \mathrm{~km}$ water depth $(\sim 0.25 \%)$ compared to those below $(\sim 0.12 \%)$, irrespective of $\mathrm{Fe}$ and $\mathrm{Mn}$ contents (table 1). 

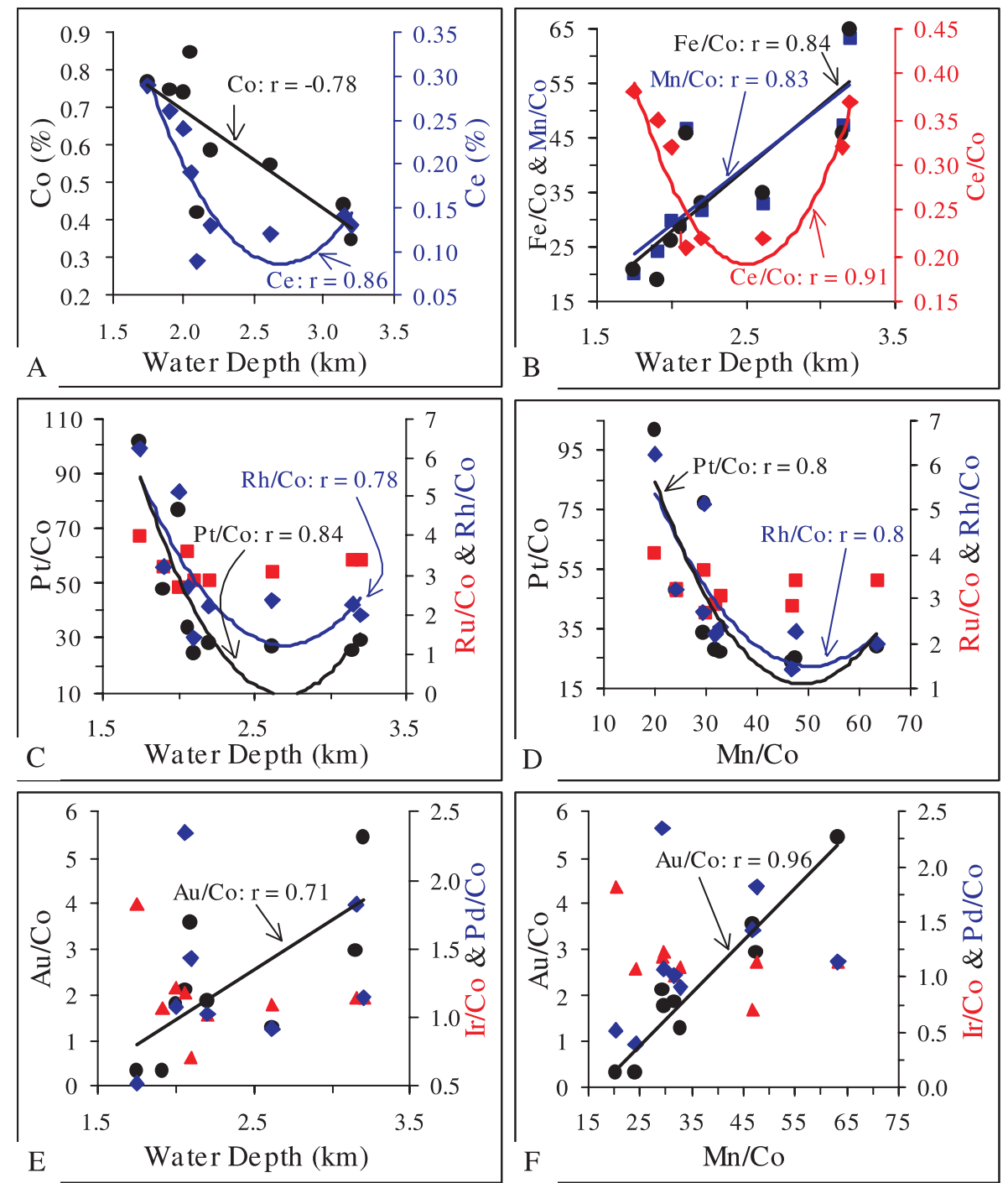

Figure 4. Major element associations with water depth and PGE-Au associations with water depth and Mn in the Afanasiy-Nikitin seamount Fe-Mn crusts. Strong negative correlation of Co and Ce (A) and positive correlations of Fe/Co and $\mathrm{Mn} / \mathrm{Co}$ (B) with water depth suggest a primary control of water depth on the composition of Fe-Mn crusts. The non-linear relationships of PGE with water depth and Mn/Co (C-F) indicate complexity of processes involved in enrichment of PGE in Fe-Mn crusts.

The lack of correlation of Fe and Mn contents with water depth $(r<0.5$; table 2$)$ is countermanded when $\mathrm{Fe}$ and $\mathrm{Mn}$ are normalized to $\mathrm{Co}$ ( $\mathrm{Fe} / \mathrm{Co}$ and $\mathrm{Mn} / \mathrm{Co}$ ), leading to strong linear positive correlations $(r>0.8$; table 2 and figure $3 \mathrm{~B})$. Thus, it is apparent that water depth exerts a primary control on the major-element chemistry of the ANS Fe-Mn crusts. Non-linear correlations of $\mathrm{Pt} / \mathrm{Co}, \mathrm{Rh} / \mathrm{Co}, \mathrm{Ir} / \mathrm{Co}$, and linear correlations of $\mathrm{Au} / \mathrm{Co}$ with water depth $(r>0.7$; figure $4 \mathrm{C}$ and $4 \mathrm{E})$ and with $\mathrm{Mn} / \mathrm{Co}(r>0.8$; figure $4 \mathrm{D}$ and $4 \mathrm{~F})$ indicate that the fractionation of $\mathrm{Pt}, \mathrm{Rh}$, and Ir in the ANS Fe-Mn crusts is associated with depthdependent $\mathrm{Fe}-\mathrm{Mn}$ hydroxide colloid precipitation. The lack of correlations of $\mathrm{Ru} / \mathrm{Co}$ and $\mathrm{Pd} / \mathrm{Co}$ with water depth, $\mathrm{Mn} / \mathrm{Co}$, and $\mathrm{Fe} / \mathrm{Co}$ (table 2 and figure $4 \mathrm{C}-\mathrm{F}$ ) suggest that $\mathrm{Ru}$ and $\mathrm{Pd}$ might follow a different pathway. To test this, the PGE-Au contents were plotted against $\mathrm{Co}$ and Ce concentrations, which are supposed to form secondary oxide phases in the ANS Fe-Mn crusts (Rajani et al 2005). Except for Pd and Au, all other PGEs show no correlation with $\mathrm{Fe}$ and $\mathrm{Mn}$ contents, but $\mathrm{Ru}$ and $\mathrm{Pt}$ show negative correlations with $\mathrm{Mn} / \mathrm{Co}$ and $\mathrm{Fe} / \mathrm{Co}$ (table 2). Interestingly, $\mathrm{Ru}$ and Ir correlate strongly with both Co and Ce $(r>0.8$; table 2 and figure 5), whereas $\mathrm{Pt}$ and $\mathrm{Rh}$ correlate only with $\mathrm{Ce}(r>0.9)$. Pd does not correlate with either Co or $\mathrm{Ce}$, and $\mathrm{Au}$ has weak negative correlations with Co and Ce (figure 5).

The chemical variations can be interpreted in two ways: 1) dominance of depth-dependent oxidation of $\mathrm{Co}, \mathrm{Ce}$, and PGE, or 2) $\mathrm{Ce}$ and PGE (except $\mathrm{Pd}$ ) have inverse linear variations with 

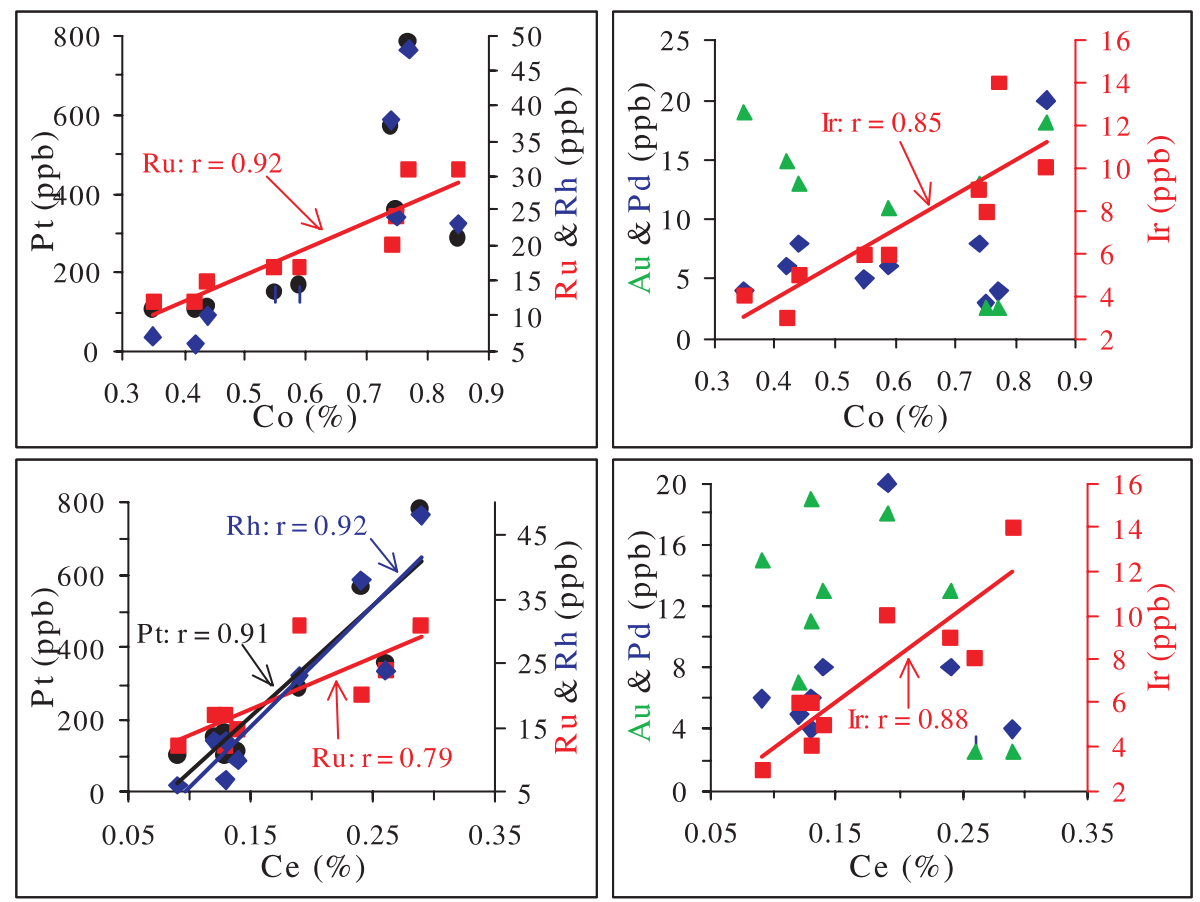

Figure 5. Scatter-plots of PGE-Au versus Co and Ce exhibiting strong positive linear correlations between most components.

water depth down to $\sim 2 \mathrm{~km}$, below which they remain more or less uniform. Both interpretation however, lead to a common idea that the PGECe are depleted in the more oxygenated water mass below $\sim 2 \mathrm{~km}$ water depth. The PGE-Ce concentrations and variations can be explained most simply as reflecting the water-depth dependent, crust growth-rate differences. The deeper water $\mathrm{Fe}-$ Mn crusts have grown at a faster rate than the shallower-water Fe-Mn crusts (Rajani et al 2005), thereby allowing short time for the acquisition of PGE, Ce, Co, etc. from seawater. Even though the oxygen content of the upper water mass is relatively low, larger concentrations of PGE, Ce, and Co resulted because of the longer time that was available for redox reactions at the $\mathrm{Fe}-\mathrm{Mn}$ crust surfaces to enrich those metals. The waterdepth distribution of metals in the crusts cannot be explained by their depletion in the deeper water mass because water-column $\mathrm{Pt}$ concentrations, for example, vary little between about 1 and $4.5 \mathrm{~km}$ water depths (Jacinto and van den Berg 1989). Data are not available for the other PGE in the Indian Ocean.

The PGE-Au fractionation in the ANS FeMn crusts thus appears to have been caused by both the rates of colloidal precipitation of Fe oxyhydroxide and $\mathrm{Mn}$ oxide and the surface adsorption and oxidation of $\mathrm{Co}, \mathrm{Ce}$ and PGE (except $\mathrm{Rh}$ and $\mathrm{Pd}$ ). The lack of correlation between $\mathrm{Pd}$ and water depth, or with major elements, highlights its fractionation from other PGE.
The paucity of surface reactions of $\mathrm{Pd}$ on $\mathrm{Mn}$ oxide and Fe hydroxide may explain its deviation from the otherwise coherent distribution of PGE. Further, strong positive correlations of the other PGE (Pt, Ru, Rh, and Ir) with $\mathrm{Co}$ and Ce (figure 5), combined with enrichment of $\mathrm{Co}$, $\mathrm{Ce}$, and $\mathrm{Pt}$ in $\mathrm{ANS} \mathrm{Fe}-\mathrm{Mn}$ crusts, must reflect the more efficient and preferential extraction of these elements from ambient seawater, which is reflected in the Pd-depleted chondrite-normalized patterns. This interpretation raises a fundamental issue: Why does the otherwise PGE-Au coherence show a different preference of $\mathrm{Pd}$ for the carrier mineral phases in the marine environment? One common thread is that the most enriched trace metals are characterized by their oxidation on the Mn-oxide and Fe-oxyhydroxide surfaces. This has been proved for Co and Ce (Murray and Dillard 1979; Takahashi et al 2000), suggested for Pt (Halbach et al 1989a; Hein et al 2003; Koschinsky et al 2005), and is undetermined for Ru and Ir. Oxidation reactions may play a key role in the concentration of all these metals. Rh has only one oxidation state, but is nonetheless strongly adsorbed, may be due to inner-sphere adsorption. Additionally, whether this kind of behavior of $\mathrm{PGE}-\mathrm{Au}$ is specific to ANS Fe-Mn crusts or is a global feature needs to be investigated. Thus $\mathrm{Pt}$ (perhaps other PGE) enrichment mechanism in $\mathrm{Fe}-\mathrm{Mn}$ crusts is not clearly understood. The previously proposed mechanisms invoked both reduction of Pt-chlorocomplexes and oxidative surface 
adsorption in presence of Mn-oxidation. The strong linear association of $\mathrm{Pt}$ (and other PGE except $\mathrm{Pd}$ ) with $\mathrm{Ce}$ and Co indicates that the PGEenrichment process is mostly oxidative. If it is true, then the documented fractionation of PGE$\mathrm{Au}$ from seawater dominated by Ce enrichment will have implications for palaeoceanographic investigations using seamount $\mathrm{Fe}-\mathrm{Mn}$ crusts as palaeowater-redox tracers.

\section{Acknowledgements}

The crew of R. V. A A Sidorenko and Boris Petrov assisted in sampling and multibeam swath bathymetric surveys respectively. V Balaram helped in interlaboratory comparison of the PGE data. Logistic support from the National Institute of Oceanography and funding support from the Department of Ocean Development are gratefully acknowledged. RPR and ARC thank the EMR of CSIR for awarding senior research fellowships. We thank M Frank for reviewing an earlier version of the manuscript and journal reviewers $\mathrm{R}$ Shankar, Steve Scott and an anonymous referee for constructive reviews and helpful suggestions. This is NIO contribution No: 4183.

\section{References}

Alvarez L W, Alvarez W, Asaro F and Michel H V 1980 Extraterrestrial cause for Cretaceous-Tertiary extinction; Science 208 1095-1108.

Anders E and Ebihara M 1982 Solar-system abundance of elements; Geochim. Cosmochim. Acta 46 2363-2380.

Aplin A C 1984 Rare earth element geochemistry of Central Pacific ferromanganese encrustations; Earth Planet. Sci. Lett. 71 13-22.

Baedecker P A 1987 Methods for geochemical analysis; U.S. Geol. Survey Bull. 1770 p. 100.

Balaram V, Mathur R, Banakar V K, Hein J R, Rao C R M, Rao T G and Dasaram B 2006 Determination of platinum group elements (PGE) and gold $(\mathrm{Au})$ in manganese nodule reference samples by nickel sulfide fire assay and Te-coprecipitation with ICP-MS; Indian J. Mar Sci. 35 $7-16$.

Banakar V K and Hein J R 2000 Growth response of a deepwater ferromanganese crust to the evolution of Neogene Indian Ocean; Mar. Geol. 162 529-540.

Banakar V K, Pattan J N and Mudholkar A V 1997 Palaeoceanographic conditions during the formation of ferromanganese crusts on the Afanasiy-Nikitin seamount, North central Indian Ocean: Geochemical evidences; Mar. Geol. 136 299-315.

Banakar V K, Galy A, Sukumaran N P, Parthiban G and Volvaiker A Y 2003 Himalayan sedimentary pulses recorded by silicate detritus within a ferromanganese crust from the Central Indian Ocean; Earth Planet. Sci. Lett. 205 337-348.

Barnes S-J, Naldrett A J and Gorton M P 1985 The origin of the fractionation of platinum-group elements in terrestrial magmas; Chem. Geol. 53 303-323.
Bertine K K, Koide M and Goldberg E D 1993 Aspects of rhodium marine chemistry; Mar. Chem. 42 199-210.

Colodner D C, Boyle E A, Edmond J M and Thomson J 1992 Post depositional mobility of platinum, iridium and rhenium in marine sediment; Nature 358 402-404.

Crocket J H 1981 Geochemistry of platinum group elements; In: Platinum group elements: mineralogy, geology, recovery (ed.) Cabri L J, Can. Insti. Min. Metall. 23 239-280.

Crocket J H and Paul D K 2004 Platinum group elements in Deccan mafic rocks: a comparison of suites differentiated by Ir content; Chem. Geol. 208 273-291.

Crocket J H and Kuo H Y 1979 Sources for gold, palladium, and iridium in deep-sea sediment; Geochim. Cosmochim. Acta 43 831-842.

De Carlo E H and McMurtry G M 1992 Rare earth element geochemistry of ferromanganese crusts from the Hawaiian archipelago, central Pacific; Chem. Geol. 95 235-250.

Esser B K and Turekian K K 1988 Accretion rate of extraterrestrial particles determined from Os-isotope systematics of Pacific pelagic clays and manganese nodules; Geochim. Cosmochim. Acta 52 1383-1388.

Frank M, O'Nions R K, Hein J R and Banakar V K 1999 60 my records of major elements and $\mathrm{Pb}-\mathrm{Nd}$ isotopes from hydrogenous ferromanganese crusts: Reconstruction of seawater paleochemistry; Geochim. Cosmochim. Acta 63 1689-1708.

Goldberg E D 1987 Heavy metal analyses in the marine environment - Approaches to quality control; Mar. Chem. 22 117-124.

Goldberg E D, Hodge V, Kay P, Stallard M and Koide M 1986 Some comparative marine chemistries of platinum and iridium; Appl. Geochem. 1 227-232.

Govett G S J 1983 Rock geochemistry in mineral exploration; Handbook of exploration geochemistry (Amsterdam: Elsevier) 3461.

Halbach P, Segl M, Puteanus D and Mangini A 1983 Relationship between Co-fluxes and growth rates in ferromanganese deposits from central Pacific seamount areas; Nature 304 716-719.

Halbach P, Kriete C, Prause B and Puteanus D 1989a Mechanism to explain the platinum concentration in ferromanganese seamount crusts; Chem. Geol. 76 95-106.

Halbach P, Sattler C-D, Teichmann F and Wahsner M 1989b Cobalt-rich and platinum bearing manganese crust deposits on seamounts: nature, formation and metal potential; Mar. Mining 8 23-39.

Hein J R and Morgen C L 1999 Influence of substrate rocks on Fe-Mn crust composition; Deep-Sea Res. I 46 $855-875$.

Hein J R, Koschinsky A, Bau M, Manheim F T, Kang J K and Roberts L 2000 Cobalt-rich ferromanganese crusts in the Pacific; In: Handbook of marine mineral deposits (ed.) Cronan D S (New York: CRC Press) pp. 239-280.

Hein J R, Koschinsky A and Halliday A N 2003 Global occurrence of tellurium-rich ferromanganese oxyhydroxide crusts and model for enrichment of tellurium; Geochim. Cosmochim. Acta 67 1117-1127.

Hein J R, Koschinsky A and McIntyre B 2005 The global enrichment of platinum group elements in marine ferromanganese crusts; In: Extended Abstracts, $10^{\text {th }}$ International Platinum Symposium, (eds) Törmänen T O and Alapieti T T, 7-11 August 2005, Oulu, Finland, p. $98-101$.

Hodge V F, Stallard M, Koide M and Goldberg E D 1985 Platinum and platinum anomaly in the marine environment; Earth Planet. Sci. Lett. 72 158-162. 
Hodge V, Stallard M, Koide M and Goldberg E D 1986 Determination of platinum and iridium in marine waters, sediments, and organisms; Anal. Chem. 58 616-620.

Jacinto G S and van der Berg C M G 1989 Different behavior of platinum in the Indian and Pacific Oceans; Nature 338 332-334.

Koide M, Goldberg E D, Niemeyer S, Gerlach D, Hodge V, Bertine K K and Padova A 1991 Osmium in marine sediment; Geochim. Cosmochim. Acta 55 1641-1648.

Koschinsky A and Hein J R 2003 Uptake of elements from seawater by ferromanganese crusts: solid-phase associations and seawater speciation; Mar. Geol. 198 331-351.

Koschinsky A and Halbach P 1995 Sequential leaching of marine ferromanganese precipitates: Genetic implications; Geochim. Cosmochim. Acta 59 5113-5132.

Koschinsky A, Audroing J and Hein J R 2005 The enrichment of platinum and fractionation of $\mathrm{Pt}$ from $\mathrm{Pd}$ in marine ferromanganese crusts; In: Extended Abstracts, $10^{\text {th }}$ International Platinum Symposium (eds) Törmänen T O and Alapieti T T, 7-11 August 2005, Oulu, Finland, p. 429-432.

Kyte F T and Wasson J T 1986 Accretion rate of extraterrestrial matter: iridium deposited 33 to 67 million years ago; Science 232 1225-1229.

Lee C A, Wasserberg G J and Kyte F T 2003 Platinum group elements and rhenium in marine sediments across the Cretaceous-Tertiary boundary: constraints on RePGE transport in marine environment; Geochim. Cosmochim. Acta 67 655-670.

Murray J W and Dillard J G 1979 The oxidation of cobalt (II) adsorbed on manganese dioxide; Geochim. Cosmochim. Acta 43 781-787.

Naldrett A J 1981 Nickel sulfide deposits: Classification, composition and genesis; Econ. Geol. 75 628-655.

Officer C B and Drake C L 1985 Terminal Cretaceous environmental events; Science 227 1161-1167.

Palmer M R and Turekian K K $1986{ }^{187}$ Os/ $/{ }^{186}$ Os in marine manganese nodules and constraints on crustal geochemistries of Re and Os; Nature 319 216-220.

Peucker-Ehrenbrink B, Bach W, Hart S R, Blusztajn J S and Abbruzzese T 2003 Rhenium-osmium isotope systematics and platinum group element concentrations in oceanic crust from DSDP/ODP Sites 504 and 417/418; Geochem. Geophys. Geosyst. 48911.
Rajani R P, Banakar V K, Parthiban G, Mudholkar A V and Chodankar A R 2005 Compositional variation and genesis of ferromanganese crusts of the Afanasiy-Nikitin Seamount, Equatorial Indian Ocean; J. Earth Syst. Sci. $11451-61$.

Sawlowicz Z 1993 Iridium and other platinum group elements as geochemical markers in sedimentary environments; Palaeogeogr. Palaeoclimatol. Palaeoecol. 104 253-270.

Sborshchikov I M, Murdmaa I O, Mataveenkov V V, Kashinstev G L, Golmshtock G I and Al'Mukhamedov A I 1995 Afanasiy-Nikitin seamount within the intraplate deformation zone, Indian Ocean; Mar. Geol. 128 115-126.

Strong C P, Brookes R R, Wilson S M, Reeves R D, Orth C J, Mao X Y, Quintana L R and Anders E 1987 A new Cretaceous-Tertiary boundary site at Faxborne River, New Zealand: Biostratigraphy and geochemistry; Geochim. Cosmochim. Acta 51 2769-2777.

Takahashi Y, Shimizu H, Usui A, Kagi H and Nomura M 2000 Direct observations of tetravalent cerium in ferromanganese nodules and crusts by X-ray absorption nearedge structure (XANES); Geochim. Cosmochim. Acta 64 2929-2935.

Turetta C, Cozzi G, Varga A, Barbante C, Capodaglio G and Cescon P 2003 Platinum group elements determination in seawater by ICP-SFMS: Initial results; J. Phys. IV 107 1321-1324.

Usui A and Someya M 1997 Distribution and composition of marine hydrogenetic and hydrothermal manganese deposits in the northwest Pacific, In: Manganese mineralization: Geochemistry and mineralogy of terrestrial and marine deposits (eds) Nicholson K, Hein J R, Buhn B and Dasgupta S, Geol. Soc. London, Spec. Publ. 119 177-198.

Vonderhaar D L, McMurtry G M, Garbe-Schönberg D, Stüben D and Esser B K 2000 Platinum and other related element enrichment in Pacific ferromanganese crust deposits; In: Marine authigenesis: From global to microbial (eds) Glenn C R, Préyôt-Lucas L, Lucas J, SEPM Spec. Publ., Tulsa, Oklahama, 66 287-308.

Wen X, De Carlo E H and Li Y H 1997 Interelemental relationship in ferromanganese crusts from the Central Pacific Ocean: Their implication for crust genesis; Mar. Geol. 136 277-297. 